Maria Ferlin har en bakgrund som ämneslärare i biologi, kemi, naturkunskap och matematik. Hon är nu doktorand i Naturvetenskap med inriktning mot utbildningsvetenskap inom forskarskolan CUL (Centrum för utbildningsvetenskap och lärarforskning) vid Göteborgs universitet, där hon är knuten till Zoologiska institutionen. Studierna bedrivs på halvtid parallellt med arbetet som universitetsadjunkt i biologi och biologiämnets didaktik på lärarutbildningen vid Högskolan i Borås, Sverige. Hennes forskningsintresse är lärande om biologisk mångfald.

MARIA FERLIN

Zoologiska institutionen, Göteborgs universitet, Sverige

Institutionen för pedagogik, Högskolan i Borås, Sverige

Maria.Ferlin@hb.se

\title{
Biologisk mångfald i svenska läroböcker för skolår 6-9
}

\begin{abstract}
This article presents a study of how different aspects of biodiversity, related to human activities, are described in six textbooks in Biology for secondary school in Sweden. It discusses the opportunities the books provide for pupils to attain the goals of the syllabus. The textbooks have been analyzed by using a quantitative content analysis with qualitative elements. The analysis has been undertaken in terms of four different aspects of biodiversity: utilitarian aspects, economic aspects, ethical aspects and aesthetic aspects. These are found in the parts of the books dealing with systematics, plants, animals, fungi, microbiology, biotechnology, the cell, ecology, etology, genetics, evolution and environmental care. The results show a variation between the textbooks in how biodiversity is defined, as well as in the proportions of the texts dealing with the issue. It is also found that the books contain faults and questionable formulations with regard to biodiversity. Finally, plausible effects of the pupils' goal-attainments are discussed in relation to the structure, formulations and contents of the books.
\end{abstract}

\section{INLEDNING}

I flertalet av Sveriges sexton miljömål betonas ambitionen att värna den biologiska mångfalden (Miljömålsportalen, 2010). Om målen ska nås krävs insatser både från myndigheter och enskilda medborgare. Men i ett allt mer urbaniserat samhälle, där nästan hälften av Sveriges invånare sällan eller aldrig besöker landsbygden (Dahl, Ericsson \& Sandström, 2009), riskerar kunskap om och ansvar för natur och miljö att gå förlorade. En undersökning visade exempelvis att barn kände igen fler tecknade Pokémonfigurer än vilda växter och djur (Balmford, Clegg, Coulson \& Taylor, 2002). Detta kan tolkas som att barn har stor potential att lära sig sådant som väcker deras intresse och kan undervisningen i biologi göras mer intresseväckande skulle också kunskapen om naturen kunna öka. Elever i tonåren rankar dock undervisning om växter och djur i närmiljön som tillhörande de minst intressanta områdena inom naturvetenskapen (Oscarsson, Jidesjö, Karlsson \& Strömdahl, 2009; Schreiner \& Sjøberg, 2004; Sjøberg, 2010). Att väcka elevers intresse för biologisk mångfald är därför en utmaning för dagens biologilärare. FN:s konvention om biologisk mångfald, fortsättningsvis förkortad CBD efter Convention of Biological Diversity, anger att 
utbildning om biologisk mångfald ska ingå i utbildningssystemet (SÖ, Statens offentliga översättningar, 1993:775, artikel 13). I kursplanen i biologi för den svenska grundskolan uttrycks också att det inte enbart handlar om ett naturvetenskapligt innehåll. "Ett av biologiämnets viktigaste bidrag till bearbetningen av människans relation till naturen är därför att belysa mångfalden av livsformer ur såväl de naturvetenskapliga som de estetiska och etiska perspektiven" (Skolverket, 2008 s. 54). En elev som lämnar grundskolan ska ha uppnått flera mål relaterade till biologisk mångfald. Denna studie syftar till att undersöka vilken hjälp att nå de målen som några vanligt förekommande biologiböcker kan erbjuda 12 till 16 år gamla elever i den svenska grundskolan.

\section{BAKGRUND}

Biologisk mångfald definieras i den här studien, i enlighet med artikel 2 i CBD, som:

variationsrikedomen bland levande organismer av alla ursprung, inklusive från bland annat landbaserade, marina och andra akvatiska ekosystem och de ekologiska komplex i vilka dessa organismer ingår; detta innefattar mångfald inom arter, mellan arter och av ekosystem (SÖ 1993:775).

Det är svårt att beskriva den biologiska mångfaldens betydelse, liksom att förutsäga tänkbara konsekvenser av förluster på gen-, art- och ekosystemnivå. Förutom vikten av att bevara mångfalden för dess egen skull, brukar också dess stora betydelse som råvarukälla och ekosystemtjänstleverentör lyftas fram för att betona människans beroende av naturen (Molander, 2008). Det ekonomiska värdet av dessa ekosystemtjänster anses vara mycket stort men svåruppskattat (Millenium Ecosystem Assessment, 2005; TEEB, 2008). Mångfalden bidrar också till estetiska upplevelser, den kan vara en källa till etiska och existentiella spörsmål och den har också ett pedagogiskt värde (Lindemann-Matthies et al., 2009; Molander, 2008). Detta lyfter också Menzel och Bögeholz (2009) fram i sin studie om ungdomars förmåga att argumentera kring bevarande av biologisk mångfald. Komplexa frågeställningar kring sådant bevarandearbete kan, enligt författarna, leda till att ungdomar utvecklar en medvetenhet om mångfaldens roll för en hållbar utveckling.

\section{Biologisk mångfald i den svenska grundskolans kursplaner}

Samtliga ämnen i den svenska grundskolan presenternas i kursplanerna genom rubrikerna; Ämnets syfte och roll i utbildningen, Mål att sträva mot, Ämnets karaktär och uppbyggnad samt Mål som eleverna skall ha uppnått i slutet av femte respektive nionde skolåret. Varken innehåll eller mål i kursplanerna detaljstyr undervisningen. De innehållsbeskrivningar av biologiämnet som görs under rubriken Ämnets karaktär och uppbyggnad samt de mål som eleverna skall ha nått när de slutar grundskolan används i denna studie som underlag för jämförelser mellan kursplaner och läroböcker. Fyra centrala områden lyfts fram i innehållet. De rubriceras Ekosystem, Biologisk mångfald, Cellen och livsprocesserna samt Människan (Skolverket, 2008, s. 54). Jämförs denna uppdelning med definitionen av biologisk mångfald i CBD så inbegriper definitionen i artikel 2 såväl ekosystem som variation mellan och inom arter. Detta innebär i sin tur att innehåll relaterat till biologisk mångfald i kursplanerna förutom under rubriken Biologisk mångfald, även finns under rubrikerna Ekosystem samt Cellen och livsprocesserna. Inom alla tre områdena anges att naturvetenskaplig kunskap ska kompletteras med etiska perspektiv. När det gäller ekosystem och biologisk mångfald nämns även estetiska perspektiv, och då särskilt när det gäller bevarandearbete och människans relation till naturen.

Definitionen från CBD användes även för att välja ut de mål i kursplanen som kan relateras till biologisk mångfald. 7 av de 17 mål som skall ha uppnåtts i biologi i slutet av nionde skolåret valdes för att studera om böckernas innehåll ger möjlighet till måluppfyllelse. I ett av dessa mål finns begreppet explicit, i ett annat genom en formulering om bevarandearbete och i de resterande genom att de berör gener, celler, arter, ekosystem eller ekosystemtjänster. 


\section{Eleven skall}

\section{beträffande natur och människa}

- ha kännedom om några av jordens ekosystem och hur organismers samverkan kan beskrivas i ekologiska termer,

- ha insikt i fotosyntes och förbränning samt vattnets betydelse för livet på jorden,

- kunna ge exempel på kretslopp och anrikning i ett ekosystem,

- ha kännedom om hur celler är byggda och hur de fungerar,

- ha kännedom om det genetiska arvet,

- känna till grunddragen i livets utveckling samt villkoren för och betydelsen av biologisk mångfald,

beträffande kunskapens användning

- kunna använda såväl naturvetenskapliga som estetiska och etiska argument i frågor om bevarande av naturtyper och mångfalden av arter samt användning av genteknik (Skolverket, 2008 s. 55-56).

De sex första målen benämns fortsättningsvis faktakunskapsinriktade mål. Det sjunde behandlar elevernas förmåga att använda sin kunskap i det bredare perspektiv som beskrivs i innehållet $\mathrm{i}$ kursplanen (Skolverket, 2008).

\section{Läroboksanalys och läroboksgranskning}

Läroböcker betraktas fortfarande som en viktig informationskälla i undervisningen. De utgör också i hög grad den kunskapsbas som lärarna undervisar utifrån (Chiappetta \& Fillman, 2007; Nelson, 2006; Selander \& Skjelbred, 2004). Både innehållet i och användningen av läroböcker i biologi har studerats åtminstone från 1960-talet och framåt. Lazarowitz (2007) drar, efter en forskningsöversikt, slutsatsen att frågeställningar och resultat varit ganska likartade genom decennierna. Han framhåller också att många studier visar att böckerna innehåller mer fakta än beskrivningar av arbetsprocesser och ämnets karaktär, även om balansen mellan faktainnehåll och annat stoff har varierat mellan olika tidsperioder.

Parallellt med analyser av hela böcker finns också studier om hur specifika ämnesområden behandlas i biologiböcker. Exempelvis fann Flodin (2009) att författarna inte var konsekventa i sin användning av genbegreppet i en läroboks olika delar. Någon motsvarande studie om hur begreppet biologisk mångfald används i en viss lärobok finns inte. En mer översiktlig studie genomfördes när Tracana, Ferreira, Ferreira och Carvalho (2008) analyserade 44 läroböcker från 13 olika länder för elever i åldrarna 6-18 år. De fann att biologisk mångfald definierades i nästan samtliga böcker. Hoten mot mångfalden beskrevs mest frekvent i böcker som vände sig till 12-15-åringar. Överlag betonades naturens estetiska värden framför problematik kring bevarandefrågor. Tracana et al. efterfrågar en högre grad av sammankoppling mellan biodiversitet och hållbar utveckling. Granquist och Mårdfjäll (2007) studerade definitionen av biologisk mångfald i svenska biologiböcker. Deras resultat visade på en stor spridning i kvaliteten på definitionerna, och att likheten med konventionstextens definition ökat med tiden.

Tracana et al. (2008) ansåg efter sin undersökning att skolmyndigheter i högre utsträckning borde uppmärksamma kvaliteten i läroböckers innehåll. En sådan granskning fanns länge i Sverige. Från 1600-talet och fram till 1991 kontrollerades bland annat att text och bilder var korrekta och pedagogiska och att innehållet stämde överens med kursplanen. Numera är det författare och förlag som står som garanter för böckernas innehåll (Långström, 1997), något som lärarna inte alltid är medvetna om då boken anses ha en "legitimerande funktion" (Skolverket, 2006 s. 50). Granskning av specifika aspekter i läroböcker ingår dock i Skolverkets uppdrag. 2006 studerades om några utvalda böcker följer den värdegrund som lyfts fram i skolans styrdokument. I rapporten betonas att en lärobok är en kompromissprodukt som också ska ha ett kommersiellt värde. Författarna har ett begränsat utrymme till sitt förfogande och måste balansera mellan kraven på forskningsbaserad kunskap och läsbarhet för målgruppen. En god lärobok är, enligt Härenstam (i Skolverket, 2006 s. 47), en "som lyckas klara den optimala kompromissen". 


\section{SYFTE OCH FRÅGESTÄLLNINGAR}

Studiens syfte är att undersöka vilka förutsättningar att nå kursplanens mål kring biologisk mångfald som användandet av någon av sex vanligt förekommande läroböcker i biologi kan erbjuda elever i grundskolans skolår 6-9 (12-16 år gamla).

Arbetet har utgått från följande frågeställningar:

- Hur förklaras och/eller definieras begreppet biologisk mångfald?

- I vilken omfattning förekommer nyttoaspekter samt ekonomiska, etiska och estetiska aspekter på biologisk mångfald relaterade till människan och mänsklig verksamhet?

- I vilken omfattning förekommer formuleringar med anknytning till biologisk mångfald, vilka skulle kunna försvåra elevers lärande?

- Vilka strategier används i böckerna för att förmedla ett naturvetenskapligt innehåll, i vilken omfattning förekommer de och hur skulle de kunna påverka elevers lärande?

- I vilken utsträckning relaterar författaren/författarna böckernas innehåll till mål i grundskolans kursplaner?

\section{METOD}

Data samlades in från de svenska biologiböcker för grundskolans senare skolår som, enligt förlagskataloger, fanns att köpa 2009. I studien benämns böckerna A-F (tabell 1).

Tabell 1 De analyserade läroböckerna

\begin{tabular}{|l|l|l|l|l|l|}
\hline & Titel & Författare & Utg.år & Uppl. & Förlag \\
\hline A & Biologi Direkt & Kukka och Sundberg & 2005 & 1 & Bonnier utbildning \\
\hline B & Biologi & Henriksson & 2002 & 2 & Gleerups \\
\hline C & Biologi (Spektrum) & Fabricius & 2006 & 3 & Liber \\
\hline D & $\begin{array}{l}\text { Biologi Light (Spek- } \\
\text { trum) }\end{array}$ & Fabricius & 2006 & 1 & Liber \\
\hline E & Biologi (Serie Puls) & Andréasson & 2007 & 3 & Natur \& Kultur \\
\hline F & $\begin{array}{l}\text { Biologi Fokus } \\
\text { (Serie Puls) }\end{array}$ & Andréasson & 2007 & 3 & Natur \& Kultur \\
\hline
\end{tabular}

Bok D är en enklare version av $\mathrm{C}$ och bok $\mathrm{F}$ är en enklare version av E. Förlagen redovisar inte försäljningssiffror, så det går inte att säga något om i vilken utsträckning de olika böckerna används.

\section{Läroböckerna studerades i fyra steg}

Då definitionen av biologisk mångfald enligt artikel 2 i CBD i korthet kan definieras som en mångfald av gener, arter och ekosystem, valde jag ut de delar av böckerna som behandlar detta innehåll. Följande ämnesområden i böckerna studerades därför: systematik, växter, djur, svampar, bakterier, bioteknik, cellen, ekologi, etologi, genetik, evolution och naturvård/miljövård/miljöproblem. Andelen sidor av det totala sidantalet i respektive bok som täcker in dessa områden, och därmed utgör underlaget för all datainsamling, är omkring $50 \%$ (tabell 2). 
Tabell 2 Urval för datainsamling

\begin{tabular}{|l|c|c|c|c|c|c|}
\hline & A & B & C & D & E & F \\
\hline Sidor i boken & 379 & 384 & 430 & 223 & 384 & 323 \\
\hline Utvalda sidor & 204 & 213 & 251 & 127 & 184 & 177 \\
\hline Andel utvalda sidor & $54 \%$ & $56 \%$ & $58 \%$ & $56 \%$ & $48 \%$ & $55 \%$ \\
\hline $\begin{array}{l}\text { Meningar på utvalda } \\
\text { sidor }\end{array}$ & 3366 & 4818 & 4545 & 2296 & 3989 & 2800 \\
\hline
\end{tabular}

Eftersom jag inte använt någon färdig modell för datainsamling och analys beskrivs studiens metod för datainsamling och analys steg för steg.

Steg 1. Inledningsvis genomfördes en kvantitativ innehållsanalys, där jag letade efter betydelsebärande enheter (Engström, 2008; Robson, 2002). Förekomsten av begreppet biologisk mångfald eftersöktes. Detta gjordes i all text, inklusive rubriker, sammanfattningar och arbetsuppgifter. Därefter studerades om, och i så fall var och hur, biologisk mångfald definieras i böckerna. Även eventuella ordlistor ingick i underlaget för denna datainsamling.

Steg 2. En deduktiv innehållsanalys genomfördes. Förekomsten av uttryck för fyra, på förhand bestämda, aspekter på biologisk mångfald relaterade till människan och mänsklig verksamhet samlades in från brödtext och bildtext. Kategorierna utgjordes av nyttoaspekter samt ekonomiska, etiska och estetiska aspekter på biologisk mångfald. Valet av dessa kategorier bygger på Molanders (2008) beskrivning av mångfaldens värden, Millenium Ecosystem Assessment (2005), samt innehåll och mål i grundskolans kursplaner (Skolverket, 2008). Slutligen beräknades andelen meningar (i procent av totala antalet meningar) som behandlade var och en av de fyra olika aspekterna i böckerna.

Steg 3. Formuleringar relaterade till biologisk mångfald vilka är felaktiga eller tveksamma ur en språklig synvinkel noterades. Formuleringar som representerar olika strategier för att förmedla innehållet till läsarna noterades också. De kvalitativa data som genererades sammanfördes till olika kategorier genom en induktiv innehållsanalys.

Steg 4. Slutligen studerades om författarna motiverar sitt stoffval för läsarna genom att explicit anknyta till styrdokument för grundskolan. En tolkning gjordes också av vilka av kursplanens mål relaterade till biologisk mångfald (Skolverket, 2008) som böckernas innehåll kan ge eleverna möjlighet att nå. Om målen för skolår 5 nåtts, är det, som nämnts ovan, sju mål kvar att uppnå i biologi, vilka kan relateras till biologisk mångfald.

All klassificering innebär en tolkning och citat används i resultatavsnittet för att ge exempel på formuleringar som representerar olika kategorier. I arbetet med att avgöra om fakta stämmer och i kategoriseringen av formuleringar har jag fått hjälp av forskare och forskarstuderande i zoologi.

\section{RESULTAT}

Resultatet följer samma steg som i redogörelsen för metoden. Inledningsvis presenteras hur och var biologisk mångfald definieras. Därefter redogörs för förekomsten av de fyra aspekterna på biologisk mångfald. Vidare presenteras faktafel, formuleringar och strategier som används i böckerna samt om författarna anknyter böckernas innehåll till mål i kursplanerna. Avslutningsvis finns, för var och en av böckerna, en sammanfattning med utgångspunkt i studiens frågeställningar och syfte. 


\section{Biologisk mångfald}

Begreppet biologisk mångfald återfinns i samtliga böcker (tabell 3). Förekomsten varierar från 4 till 17 gånger om all text i de utvalda avsnitten medräknas. Studeras enbart brödtext och bildtext är spannet från 1 till 11 gånger.

Tabell 3 Antal gånger begreppet "biologisk mångfald" förekommer i läroböckerna

\begin{tabular}{|l|c|c|c|c|c|c|}
\hline & A & B & C & D & E & F \\
\hline $\begin{array}{l}\text { Biologisk mångfald nämns i alla former } \\
\text { av text }\end{array}$ & 5 & 4 & 17 & 13 & 11 & 7 \\
\hline $\begin{array}{l}\text { Biologisk mångfald nämns i brödtext/ } \\
\text { bildtext }\end{array}$ & $1 / 0$ & $2 / 0$ & $7 / 4$ & $4 / 2$ & $6 / 0$ & $5 / 1$ \\
\hline Biologisk mångfald förklaras explicit & $\mathrm{Ja}$ & $\mathrm{Nej}$ & $\mathrm{Nej}$ & $\mathrm{Nej}$ & $\mathrm{Ja}$ & $\mathrm{Ja}$ \\
\hline
\end{tabular}

Biologisk mångfald definieras explicit, implicit och inte alls. I böckerna $\mathrm{E}$ och $\mathrm{F}$ finns i brödtexten en förklaring som överensstämmer med artikel 2 i CBD. Författarna inkluderar arter, varianter inom arter och ekosystem i sin definition. Även i A finns motsvarande förklaring, men i ordlistan. I böckerna C och D förklaras begreppet implicit genom meningen "Det har fört med sig att den biologiska mångfalden minskat - antalet arter och livsmiljöer har blivit färre" (C s. 172). I B finns ingen förklaring till vad biologisk mångfald är.

\section{Aspekter på biologisk mångfald}

När det gäller förekomsten av de olika aspekterna på biologisk mångfald relaterad till människan och mänsklig verksamhet varierar den från 0,3 till 6,6 \% av det totala antalet meningar i de utvalda avsnittens bröd- och bildtexter (tabell 4).

Tabell 4 Förekomsten av olika aspekter på biologisk mångfald i läroböckerna

\begin{tabular}{|l|c|c|c|c|c|c|}
\hline & A & B & C & D & E & F \\
\hline Nyttoaspekter & 3,5 & 3,4 & 6,6 & 6,6 & 5,3 & 5,6 \\
\hline Ekonomiska aspekter & 0,4 & 0,3 & 0,3 & 0,4 & 0,6 & 0,4 \\
\hline Etiska aspekter & 2,4 & 1,5 & 2,7 & 2,8 & 4,8 & 3,1 \\
\hline Estetiska aspekter & 1,5 & 1,4 & 1,9 & 1,6 & 1,1 & 1,2 \\
\hline
\end{tabular}

Nyttoaspekter på biologisk mångfald är den aspekt som lyfts fram i störst utsträckning i böckerna, även om procentsatsen är nästan dubbelt så stor i C och D, jämfört med A och B. Som exempel på formuleringar som klassificerats som nyttoaspekter kan nämnas både nutida användning "Raps odlas och används vid margarinframställning" (B s. 33) och hur mångfalden nyttjats längre tillbaka i tiden "Denna egenskap utnyttjades förr i blöjor och sårförband" (B s. 39). Även mer generell nytta av biologisk mångfald i form av ekosystemtjänster har räknats med i denna kategori exempelvis "De tillverkar också den största delen av det syre som finns på vår jord" (A s. 98). Nyttoaspekter lyfts ofta fram i avsnitten om bakterier och genteknik.

Ekonomiska aspekter på biologisk mångfald är den aspekt som betonas minst i samtliga böcker. Kategorin innefattar meningar som har en tydlig ekonomisk anknytning som "Idag försöker forskare också räkna ut värdet av att ekosystemet fungerar" (E s. 124) och "Det gör att priserna på 
de genförädlade fröerna kan bli för höga för en fattig bonde” (E s. 294). Men också meningar som visar på en indirekt ekonomisk aspekt har medräknats, såsom "Snytbaggen gör stor skada i skogen när den gnager av barken på trädplantor” (E s. 41).

Etiska aspekter på biologisk mångfald förekommer i alla böcker med högst förekomst i E. Aspekterna återfinns främst i avsnitt som handlar om genteknik "Vet vi tillräckligt mycket om vad som händer när vi sätter in främmande gener?" (E s. 295) och miljöfrågor exempelvis "Vi gör om ekosystemen så att de ska passa oss när vi odlar och bygger städer och vägar" (E s. 114).

Estetiska aspekter på biologisk mångfald används för att associera till såväl positiva som negativa sinnesupplevelser. "Där bildar de vackra mönster som liknar kartor" (C s. 47) och "Efter en härlig skogstur är det skönt att komma hem och kanske njuta av en varm macka med stekta kantareller" (C s. 45) visar på både skönhetsupplevelser och positiva smakupplevelser till följd av en biologisk mångfald. Ett exempel på motsatsen är "Övergödning till havs kan förvandla vattnet till en gulgrön sörja" (C s. 198). När det gäller estetiska aspekter på biologisk mångfald återfinns den högsta andelen i C.

De olika aspekterna på biologisk mångfald relaterade till människan och mänsklig verksamhet förekommer således i samtliga böcker. Det finns en variation både mellan vilken tyngd författarna valt att lägga på de olika aspekternas förekomst, och hur stor del av det totala antalet meningar som ägnas åt dessa aspekter. Adderas värdena erhålls en skillnad från 6,6 \% av meningarna i B till $11,8 \%$ av meningarna i E.

\section{Faktafel, formuleringar och strategier}

Faktafel och formuleringar med anknytning till biologisk mångfald, vilka skulle kunna försvåra elevers lärande noterades. En induktiv analys gjordes, vilken genererade fyra olika kategorier (tabell 5). De två sista representerar strategier, som används för att förmedla böckernas innehåll till läsarna.

Tabell 5 Faktafel, formuleringar och strategier

\begin{tabular}{|l|c|c|c|c|c|c|}
\hline & A & B & C & D & E & F \\
\hline Faktafel & 32 & 10 & 12 & 2 & 3 & 4 \\
\hline Språkligt tveksamma formuleringar & 13 & 7 & 3 & 11 & 14 & 5 \\
\hline Förenklingar och vardagliga uttryck & 31 & 25 & 37 & 27 & 30 & 22 \\
\hline Antropomorfism & 16 & 26 & 31 & 12 & 28 & 25 \\
\hline
\end{tabular}

Faktafel finns inom en rad olika ämnesområden och är av varierande komplexitetsgrad, vilket följande tre citat exemplifierar. "Fåglarna är de enda ryggradsdjur som kan flyga" (D s. 58), "När en clownfisk anfaller förvandlas bläckfisken till en randig, mycket giftig havsorm" (A s. 27) och

Det är kroppens yttre delar som står i kontakt med omgivningen. De yttre delarna hos djur, växter och svampar förändras därför snabbast. När miljöerna förändras tar det längre tid för de inre delarna att förändras. [...] De delarna som ändras långsammast är genernas DNA och andra kemiska ämnen vi har i kroppen (A s. 305).

Även bland bildtexter finns faktafel som räknats med i ovanstående tabell. Det kan vara en förväxling mellan två olika mossarter (A s. 82) eller en bildtext om gifternas koncentration uppåt $\mathrm{i}$ näringskedjan där författarna berättar om hur örnar och sälar får i sig mycket gift samtidigt som bilden visar en fiskgjuse (C s. 201). Denna kategori innehåller också ett fåtal formuleringar, vilka 
visar på att författarna inte anammat aktuell forskning. Inom systematik används namn på grupper som inte är monofyletiska, dvs. "naturliga" i ett evolutionärt perspektiv. Även inom ekologin lever äldre begrepp kvar.

Språkligt tveksamma formuleringar finns i varierande grad. Ofta rör det sig om syftningsfel som "Den sitter ofta på stolpar längs vägarna och spanar efter påkörda djur eller annat som passerar förbi." (A s. 61, om en ormvråk, min anm.) och "Under huden finns djurens taggar. De största kan bli 1 meter långa och väga 10 kg” (D s. 47, om sjögurkor, min anm.). I denna kategori har jag även placerat meningar vilkas innehåll inte är språkligt felaktiga men ändå kan påverka möjligheter till lärande, såsom "Ormar är rovdjur som saknar armar och ben" (B s. 107), " "Armarna" är inte riktiga armar utan delar av själva kroppen" (E s. 33, om sjöstjärnor, min anm.) och "Däggdjur i kalla områden har ofta päls för att inte frysa" (C s. 109).

Förenklingar och vardagliga uttryck förekommer i samtliga böcker. Återkommande förenklingar är att alla fiskar har yttre befruktning och att resultatet av nedbrytning enbart blir jord, åtminstone på något ställe i samtliga böcker. Förenklingarna är inte alltid konsekvent genomförda inom den aktuella boken. I likhet med Flodins (2009) resultat framkommer även i denna studie en inkonsekvens mellan olika avsnitt i en och samma bok. Att "De döda organismerna bryts ner i mindre delar och blir jord" kan vi läsa i E (s. 21) medan resultatet av nedbrytningen på ett annat ställe i samma bok är närsalter "Nedfallande blad och andra döda växtdelar angrips omedelbart av nedbrytare och kvar blir bara närsalter" (E s. 102). På nästa sida blir det istället mull "Många växter är rotade i den mull som bildas i grenklykor genom förmultning av nedfallande blad och andra växtdelar" (E s. 103) och slutligen blir resultatet av nedbrytningen att "Förnan bryts ner av nedbrytarna till nya råvaror, bland annat koldioxid, vatten och närsalter" (E s. 116). Avsaknad av konsekvens mellan uppgifter inom samma bok förekommer inte bara i samband med nedbrytningsprocessen. Om det anges att "En vanlig gissning är att det finns 10-20 miljoner olika organismer på vår jord" (A s. 3), kan det vara problematiskt att det längre bak i boken står att "biologer tror att det finns ungefär 20 miljoner arter bakterier" (A s. 100).

Användning av vardagliga uttryck istället för naturvetenskapligt korrekta förekommer i samtliga böcker. "Det försvinner ju en hel del energi på vägen eftersom det går åt energi i organismerna när de lever och växer" (F s. 107) och "En hare som äter gräs förbrukar ca $90 \%$ av matens energi” (B s. 147) visar på en vardaglig användning av energibegreppet. "Tyngst är vattnet vid $+4{ }^{\circ} \mathrm{C}$ " (C s. 164) och "Så här fortsätter det till hela DNA-molekylen förvandlats till två DNA-molekyler" (E s. 323) är andra exempel på vardagliga uttryck. I kategorin återfinns också formuleringar om hur organismer anpassar sig till miljön utan ett bakomliggande evolutionsbiologiskt resonemang. "Hos fiskar som ständigt lever i mörker har ögonen med tiden försvunnit helt" (C s. 93) är ett av många exempel på sådana formuleringar.

Antropomorfistiska formuleringar innebär ett förmänskligande av olika organismer. "Korsspindeln väntar tålmodigt vid sitt vackra fångstnät" (B s. 83) och "Ger vi dem växtnäring piggnar de oftast till" (C s. 136) är två exempel ur den rika floran av antropomorfistiska formuleringar. Flertalet exempel är av typen "Mångfotingar tycker inte om ljus" (E s. 36) och "I tjocktarmen trivs kolibakterier och många andra bakterier" (F s. 22).

Utöver ovanstående kategorier förekommer även andra formuleringar som skulle kunna försvåra elevers lärande. Något som varierar både mellan och inom böckerna är hur författarna ser på människan. Vi växlar mellan att vara ett djur bland andra däggdjur och något, oklart vad, som finns vid sidan av djuren. I E särskiljs på flera ställen människan från djuren; "Vi liknar på många sätt andra djur men så här skulle inget annat djur kunna göra" (E s. 136). Även författarna till D väljer att både inkludera och exkludera människan i relation till djuren "Vi människor är däggdjur. Det som skiljer oss mest från de övriga djuren är vår välutvecklade hjärna” (D s. 61). Andra formuleringar 
i böckerna skiljer ut oss än mer från djuren. "Efter en tid hade bakterierna förändrat miljön så att den kom att passa för högre växter och djur och även människor" (F s. 312) är exempel på hur författarna ger människan en särställning.

Utöver de faktafel som medräknats i tabell 5, förekommer också formuleringar som inte är felaktiga men där det finns alternativ som är bättre ur en biologisk synvinkel. Som exempel kan nämnas näringskedjor där födovalen inte är de vanligaste för de ingående organismerna. En ormvråk är ett bättre val än en duvhök när en rovfågel ska äta en mus. Det finns också fackuttryck inom biologin som kan vara svåra för eleverna att förstå om de inte förklaras. Uttrycket "högre växter" (F s. 132) är en sådan formulering. Det är heller inte sannolikt att alla elever vet vilket kön ståndare och pistiller representerar om det inte anges i texten (B s. 23).

\section{Relationen mellan läroböckernas innehåll och grundskolans kursplaner}

Studiens syfte är att undersöka vilka förutsättningar att nå kursplanens mål kring biologisk mångfald som användandet av någon av sex vanligt förekommande läroböcker i biologi kan erbjuda elever i grundskolans skolår 6-9. Resultatet visar att det finns varierande möjligheter för elever att med hjälp av innehållet i böckerna nå målen de skall ha uppnått i slutet av det nionde skolåret med anknytning till biologisk mångfald. Inga författare relaterar explicit till mål i grundskolans kursplaner men böckernas innehåll motsvarar i hög grad kursplanernas innehåll. Eleverna ges därmed möjligheter att nå främst de faktakunskapsinriktade målen. Överlag är det målet "kunna använda såväl naturvetenskapliga som estetiska och etiska argument i frågor om bevarande av naturtyper och mångfalden av arter samt användning av genteknik" (Skolverket, 2008, s. 56) som böckernas innehåll täcker sämst och där variationen är störst mellan böckerna.

Med utgångspunkt i studiens frågeställningar presenteras avslutningsvis en sammanfattning bok för bok där särskild uppmärksamhet ägnas relationen mellan böckernas innehåll och kursplanernas mål.

Bok A. Biologisk mångfald definieras i enlighet med CBD. Detta sker i ordlistan i slutet av boken. När det gäller de olika aspekterna på biologisk mångfald som eftersökts i studien förekommer de ungefär i samma utsträckning som i övriga böcker med undantag av nyttoaspekter, som beskrivs förhållandevis litet. Innehållet är aktuellt när det gäller ekosystemtjänsterna, vilket bidrar till att den biologiska mångfaldens betydelse ändå behandlas i boken. A är den bok som innehåller flest faktafel. Möjligheten att nå kursplanens mål finns men några av faktafelen kan försvåra måluppfyllelse och boken utmanar inte explicit till argumentation kring bevarandearbete.

Bok B. Biologisk mångfald förklaras inte i boken. Begreppet introduceras i ett avsnitt om lavar och luftföroreningar. B är den bok som ägnar minst utrymme åt de i studien eftersöka aspekterna på biologisk mångfald. Däremot är den innehålls- och informationsrik. Bokens innehåll svarar främst mot de faktakunskapsinriktade målen . De faktafel som förekommer berör huvudsakligen detaljer. På två "Klarar du detta"-sidor uppmanas eleverna att ta reda på mer om biologisk mångfald men innehållet i B utmanar inte till den mångfacetterade argumentation kring bevarandearbete som eleverna ska vara kompetenta att klara av efter skolår nio.

Bok C. Biologisk mångfald introduceras tidigt i C, där det redan på sidan 12 sägs att det är "viktigt att bevara en stor biologisk mångfald med många olika arter". Begreppet återkommer sedan på många ställen i boken dock utan en explicit definition. De eftersökta aspekterna på biologisk mångfald förekommer förhållandevis rikligt och nyttoaspekterna betonas mest. C är den bok där estetiska aspekter ges störst utrymme. De faktafel som förekommer är även i C med få undantag på detaljnivå. Den förenkling som skulle kunna försvåra lärande om ekosystemtjänsterna är att nedbrytning oftast resulterar i jord. Möjligheten att nå målen kring biologisk mångfald är goda även om det krävs aktivt arbete av eleverna för att samla argument kring bevarandearbete. 
Bok D. Då boken är en förenklad version av C följer den samma upplägg. Biologisk mångfald introduceras tidigt och med samma förklaring även i D. Begreppet återkommer sedan ofta i boken. Precis som i C är det nyttoaspekterna som betonas mest. Faktafelen är få. Vardagliga uttryck och förenklingar kan relateras till bokens ambition att vara mer lättillgänglig. Möjligheten att nå målen kring biologisk mångfald är förhållandevis goda men bokens innehåll utmanar inte specifikt till argumentation kring bevarandearbete.

Bok E. I boken ges begreppet biologisk mångfald, dess definition och olika argument kring bevarande ett eget uppslag. Definitionen följer CBD och författarna hänvisar till konventionen i en faktaruta. Det finns också arbetsuppgifter som berör biologisk mångfald. De eftersökta aspekterna förekommer i ganska stor utsträckning med extra tonvikt på de etiska. Faktafelen är få men ekosystemtjänsten nedbrytning presenteras inte konsekvent. Möjligheten att nå målen kring biologisk mångfald är goda.

Bok F. Då boken är en förenklad version av E ges även i F utrymme för samma definition av biologisk mångfald och en likartad förekomst av de olika aspekterna. Däremot finns inte motsvarande utmanande arbetsuppgifter som i E. Faktafelen är få. Förekomsten av förenklingar och vardaglig NO kan, precis som för D, relateras till bokens målgrupp. Möjligheten att nå målen kring biologisk mångfald är förhållandevis goda men boken utmanar inte specifikt till argumentation kring bevarandearbete.

\section{Diskussion}

Inledningsvis diskuteras metoden och dess tänkbara påverkan på resultatet. Därefter diskuteras resultaten i samma ordning som i resultatavsnittet. Alla delar knyts till studiens syfte. Avslutningsvis diskuteras studiens resultat i ett vidare sammanhang, samt dess möjliga implikationer för lärare, för lärarstudenter och för fortsatt forskning.

\section{Diskussion av metoden}

Eftersom insamling och analys bygger på tolkningar genomförda av en person är det oundvikligt att det finns subjektiva moment i resultaten. För att minska subjektiviteten har professionellt verksamma zoologer deltagit i arbetet med klassificering. Dessutom har jag kontrollerat min tolkning genom att genomföra kategoriseringar av samma material vid upprepade tillfällen. När det gäller förekomsten av faktafel, formuleringar och strategier finns också risk för subjektiva tolkningar. Klassificeringarna har gjorts efter diskussion med zoologer och ämnesdidaktiker och även i denna analys har kategoriseringarna upprepats.

Biologisk mångfald kan studeras ur en rad olika perspektiv. Det finns två huvudsakliga skäl till att de fyra aspekterna på biologisk mångfald relaterades till människan och mänsklig verksamhet. Det första är att avgränsningen skulle varit svår om nyttoaspekter på biologisk mångfald skulle innefattat även inbördes nytta mellan olika organismer. Det andra är att studier visar att tonåringar rankar sitt intresse för naturvetenskap högre om den relateras till människan och mänsklig verksamhet (Oscarsson, Jidesjö, Karlsson \& Strömdahl, 2009; Schreiner \& Sjøberg, 2004). Det var därför intressant att se om detta avspeglas i författarnas stoffval.

\section{Biologisk mångfald}

Resultatet visar att det är stor variation både i antal gånger biologisk mångfald nämns i böckerna (tabell 3) och i hur det definieras. En explicit definition saknas i hälften av böckerna. Författarna överlåter därmed åt läsaren att själv tolka och definiera begreppet. Eftersom biologisk mångfald är ett av fyra centrala områden inom biologiämnet skulle bristen på såväl användning av begreppet, som en korrekt förklaring av vad det innebär, kunna försvåra för eleverna att nå kursplanens mål relaterade till biologisk mångfald. En förklaring som bygger på CBD:s definition kan troligen öka elevernas möjlighet till måluppfyllelse. 


\section{Aspekter på biologisk mångfald}

Förekomsten av de olika aspekterna på biologisk mångfald varierar mellan böckerna (tabell 4). Den aspekt som lyfts mest i samtliga böcker är nyttoaspekter, ett innehåll som kan motiveras med att eleverna ska känna till "betydelsen av biologisk mångfald" (Skolverket, 2008 s. 55). Mångfaldens ekonomiska värden kan också räknas till "betydelsen av biologisk mångfald" (a.a. s. 55). Den ekonomiska aspekten ägnas dock litet utrymme i böckerna, trots att det ekonomiska värdet av biologisk mångfald allt mer lyfts fram i samhällsdebatten som ett argument för bevarandearbete (Millenium Ecosystem Assessment, 2005; TEEB, 2008). I kursplanerna uttrycks explicit i såväl innehåll som mål att etiska och estetiska perspektiv ska ingå i biologiundervisningen. Perspektiven förekommer i böckerna men de skulle behöva stärkas för att svara mot kursplanernas formuleringar.

Resultatet visar också att en mycket stor del av brödtexten inte behandlar de fyra aspekter som eftersökts i denna studie. De utgörs istället av den koncentration av fakta, som även tidigare forskning visat att läroböcker till stor del består av (Chiappetta \& Fillman, 2007; Lazarowitz, 2007). Det finns troligen möjligheter att väcka ökat intresse för biologi genom att i större utsträckning än som sker i dagens böcker, betona de aspekter som eftersökts i studien. Vårt beroende av naturens ekosystemtjänster skulle kunna lyftas fram betydligt mer, liksom tänkbara konsekvenser om vi inte kan hejda förlusten av mångfaldens komponenter. Många människor har liten kontakt med naturen (Dahl, Ericsson \& Sandström, 2009) och ringa förståelse för vårt beroende av naturens tjänster. Menzel och Bögeholz (2009) och Tracana et als (2008) önskan att eleverna utmanas att upptäcka den biologiska mångfaldens betydelse för en hållbar utveckling kan gälla även för de svenska böckerna. Komplexa frågor relaterade till människans livsvillkor och påverkan på naturen skulle kunna få en mer framträdande plats. Det kan bidra till ökad möjlighet för eleverna att delta i de diskussioner om bevarande av biologisk mångfald, med såväl naturvetenskapliga som estetiska och etiska argument, som de ska vara kompetenta till.

\section{Faktafel, formuleringar och strategier}

Elever och lärare bör kunna lita på att böckernas innehåll är korrekt. Att över 30 faktafel finns kvar vid publicering är olyckligt. Ansvaret för granskningar ligger numera på författare och förlag och studiens resultat tyder på att mer tid och resurser behöver läggas på sådan granskning. Ämneskunniga experter behöver engageras i arbetet med att få innehållet korrekt och aktuellt. Faktafel förekommer i alla böcker men i olika utsträckning och av varierande komplexitet. Citatet gällande evolution från bok A (s. 305) visar att en del felaktiga formuleringar kan vara problematiska att genomskåda för många elever. En sådan beskrivning riskerar att försvåra för eleverna att nå kursplanens mål " känna till grunddragen i livets utveckling samt villkoren för och betydelsen av biologisk mångfald" (Skolverket, 2008 s. 55). Den kan dessutom bidra till utvecklande av vardagsuppfattningar.

Att förenkla och använda vardagliga uttryck istället för naturvetenskapligt korrekta sådana torde alltid kunna bli föremål för diskussioner och prioriteringar i strävan mot den "optimala kompromissen" (Skolverket, 2006 s. 47). Böckernas utrymme är begränsat, vilket kan vara en orsak till uttryck som "växter är helt enkelt gröna" (A s. 76). Användandet av förenklingar är troligen också en nödvändig strategi för att skapa intresse för biologi hos flertalet elever. Böckernas innehåll presenteras inte så att eleverna medvetandegörs om att denna strategi används. Författarna skulle kunna förklara sina överväganden i texter som vänder sig direkt till eleverna. De förord som finns idag vänder sig, med undantag av det i E, inte till eleverna. Här finns en outnyttjad möjlighet att kommunicera med läsarna. Istället för "I det här avsnittet får du lära dig att” i början på ett kapitel skulle författarna kunna skriva en introduktionstext till avsnittet, där de förklarar sina överväganden.

Det är en vanlig strategi att använda antropomorfistiska formuleringar men om detta försvårar eller underlättar elevers lärande besvarar inte den här studien. Den målgrupp som de analyserade böckerna vänder sig till torde i större omfattning kunna klara sig utan ett förmänskligande av växter och djur. 
En konsekvent användning av biologiska begrepp i bokens olika delar är en fråga om noggrann bearbetning, tillgång till ämneskunniga granskare och samråd mellan författarna om flera är inblandade. En av mångfaldens viktigare ekosystemtjänster är att bryta ner döda organismer så att det åter bildas koldioxid och vatten, samtidigt som mineralämnen frigörs. Om resultatet av nedbrytning i de analyserade böckerna i stor utsträckning bara utgörs av jord eller om resultaten av nedbrytningen varierar mellan olika avsnitt inom samma bok kan målen att "kunna ge exempel på kretslopp" och att "ha insikt i fotosyntes och förbränning" (Skolverket, 2008 s. 55) bli svåra att nå.

Att skriva lockande och förståeligt för tonåringar men ändå korrekt ur naturvetenskaplig synvinkel är en utmaning. Författarna till bok A beskriver denna uppgift på följande sätt "Vi har försökt att på ett enkelt sätt beskriva det svårbegripliga" (A s. III). Resultaten pekar på att det finns utvecklingsmöjligheter i dagens läroböcker. Elever i skolår 6 till 9 är en heterogen målgrupp gällande såväl intresse som förkunskaper och mognad. Yasan och Seremet (2007) föreslår att böcker ska tas fram i team där, utöver ämnesexperter, även medarbetare som är experter på pedagogik, bildpsykologi och layout ska ingå. Det vore intressant att dessutom inbjuda elever och yrkesverksamma lärare att ingå i sådana team där formuleringar och strategier diskuteras.

\section{Relationen mellan läroböckernas innehåll och grundskolans kursplaner}

Böckernas innehåll stämmer i stor utsträckning överens med innehåll och mål i grundskolans kursplaner, vilket knappast är förvånande, då skolans styrdokument bör vara en utgångspunkt för läroboksförfattarna. Den här relationen lyfts dock inte explicit fram i någon av böckerna trots att böckernas innehåll får anses som en betydande komponent när eleverna ska ges möjlighet att nå angivna mål. Läroboksförfattare skulle kunna skapa bryggor mellan läroböckernas text och kursplanernas mål för att hjälpa eleverna att strukturera sitt lärande. Inte i några av böckerna som analyserats finns sådana bryggor. Frånvaron av dessa kan bero på att böckernas innehåll styrs mer av tradition än av styrdokument. Lärare och elever behöver därför ägna tid åt att tolka såväl kursplanernas som läroböckernas formuleringar för att skapa struktur på lärandet i biologi. Det kan finnas vinster i att tolkningarna av målen görs av lärare med pedagogisk och didaktisk kompetens. Men ökad samverkan mellan styrdokument och lärobokstexter skulle kunna bidra till att eleverna får lättare att upptäcka samband mellan lärobokens innehåll och kursplanernas mål.

Studiens syfte var att undersöka vilka förutsättningar att nå kursplanens mål kring biologisk mångfald som användandet av någon av sex vanligt förekommande läroböcker i biologi kan erbjuda elever i grundskolans skolår 6-9. Resultatet visar att det finns en spridning i hur väl böckerna kan tillgodose elevers möjligheter till måluppfyllelse inom det område som studien omfattat. Jag betonar att det är en begränsad del av böckerna som varit föremål för analys. Böckernas potential i relation till samtliga mål som skall ha uppnåtts i slutet av nionde skolåret har inte undersökts. Kursplanernas mål att sträva mot har heller inte omfattats av denna studie.

\section{Avslutning och framåtblick}

Läroböckers betydelse i dagens multimodala informationsflöde kan diskuteras, liksom om det är värt att lägga energi på läroboksanalyser när många skolor inte satsar sina resurser på läromedelsinköp. Enligt Lazarowitz (2007) används läroböcker mycket frekvent. Nelson (2006) skriver att läroboken i naturvetenskapliga ämnen utgör "en betydande del av undervisningen och kommer med största sannolikhet att göra så under lång tid framåt" (s. 16). När många NO-lärare är just NO-lärare och inte biologilärare med många ämnesteoretiska poäng i sin lärarutbildning, utgör läroboken en trygghet $i$ arbetet för både lärare och elever. Denna studie visar att valet av lärobok kan ha betydelse för elevers möjligheter att nå de mål som Skolverket (2008) anger att de ska nå. Medvetenheten om hur läroböcker är framtagna och att det inte finns ett garanterat samband mellan böckernas innehåll och kursplanernas mål behöver ökas. Studier av läroböcker kan därför anses ha giltighet för både lärarstudenter och yrkesverksamma lärare. 
Den statliga läromedelsgranskningen bidrog enligt Långström (1997) till en likriktning bland svenska läroböcker. Även de biologiböcker som erbjuds dagens elever är sinsemellan likartade. Stoffet i böckerna kan ses som en kortversion av biologiämnet på universitetsnivå. Kanske är det dags att lämna det traditionella upplägget bakom sig och arbeta fram böcker där innehållet anpassas till forskningsresultat som visar vad som kan väcka barns och ungdomars intresse och vilka vardagsföreställningar som behöver utmanas för att stimulera till lärande. När elever har tillgång till en obegränsad informationsmängd via Internet, skulle tonvikten i böckernas innehåll kunna ändras. Istället för presentation av fakta kan ökat utrymme ägnas åt grundläggande sammanhang, naturvetenskapliga arbetssätt och processer samt att presentera biologiämnet som ett kunskapsområde i utveckling. Det skulle vara intressant med forskning kring hur ett sådant upplägg tas emot av elever och lärare. I en föränderlig värld, där den biologiska mångfalden är hotad, kommer nyfikna och engagerade biologer att behövas, liksom naturvetenskapligt allmänbildade medborgare. Förändrade läroböcker kan vara en väsentlig komponent när dessa biologiskt kunniga medborgare ska utbildas. Behovet är stort med tanke på såväl befintliga som framtida utmaningar både nationellt och globalt.

\section{TACK}

Jag vill avslutningsvis tacka mina handledare Per Sundberg och Anita Wallin, som kommit med mycket värdefulla synpunkter under arbetets gång. Tack också till arbetskamrater vid Högskolan i Borås samt doktorandkollegor både på Zoologiska institutionen och i mitt CUL-tema som inspirerat och kritiserat. Ett stort tack till de, för mig okända, referees som tog sig tid att läsa och kommentera mitt ursprungliga manus.

\section{REFERENSER}

Andréasson, B. (2007a). Biologi: för grundskolans senare del. 3. uppl. Stockholm: Natur och Kultur.

Andréasson, B. (2007b). Biologi: för grundskolans senare del. Fokus. 3. uppl. Stockholm: Natur och Kultur.

Balmford, A., Clegg, L., Coulson, T., \& Taylor, J. (2002). Why conservationists should heed Pokémon. Science 295(5564), 2367.

Chiappetta, E., \& Fillman, D. (2007). Analysis of five high school biology textbooks used in the United States for inclusion of the nature of science. International Journal of Science Education, 29(15), 1847-1868.

Dahl, F., Ericsson, G., \& Sandström, C. (2009). Färre svenskar lämnar asfaltsdjungeln. Miljötrender 3, 3-5 Erhållen Nov 25, 2009 från http://www2.slu.se/foma/mt09/MT3_09.pdf

Engström, S. (2008). Fysiken spelar roll!: Undervisning om hållbara energisystem: Fokus på gymnasiekursen fysik $A$. Lic-avh. Västerås: Mälardalens högskola.

Fabricius, S. (2006a). Biologi [Grundbok]. 3.,[rev] uppl. Stockholm: Liber.

Fabricius, S. (2006b). Biologi. Light. 1.uppl. Stockholm: Liber.

Flodin, V. (2009). The Necessity of Making Visible Concepts with Multiple Meanings in Science Education; The Use of the Gene Concept in a Biology Textbook. Science \& Education, 18 (1), 73-94.

Granquist, A., \& Mårdfjäll, E. (2007). Jag trivs bäst när havet svallar, och måsarna ger skri. En textanalytisk studie av biologisk mångfald i några läroböcker. C-uppsats. Södertörn: Södertörns högskola.

Henriksson, A. (2002). Gleerups Biologi. 2., [rev. och uppdaterade] uppl. Malmö: Gleerup.

Kukka, J., \& Sundberg, CJ. (2005). Biologi direkt. Stockholm: Bonnier utbildning.

Lazarowitz, R. (2007). High school biology curricula development: Implementation, teaching and evaluation from the twentieth to the twenty-first century. I S. Abell \& N. Lederman (Eds.), Handbook of Research on Science Education (s.561-598). Mahwah, NJ: Lawrence Erlbaum Associates, Publishers. 
Lindemann-Matthies, P., Constantinou, C., Junge, X., Kohler, K., Mayer, J., Nagel, U. et al. (2009). The integration of biodiversity education in the initial education of primary school teachers: four comparative case studies from Europe. Environmental Education Research, 15(1), 17-37, Erhållen Nov 25, 2010 från <http://ejournals.ebsco.com/direct.asp?ArticleID=47FE8A8B21 1B64858116>

Långström, S. (1997). Författarröst och lärobokstradition: en historiedidaktisk studie = The textbook tradition and the voice of the author: a study in history and didactics. Diss. Umeå: Umeå Universitet.

Menzel, S., \& Bögeholz, S. (2009). The Loss of Biodiversity as a Challenge for Sustainable Development: How Do Pupils in Chile and Germany Perceive Resource Dilemmas? Research in Science Education 39 (4), 429-447

Miljömålsportalen (2010). Erhållen Okt 4, 2010 från http://miljomal.nu

Millenium Ecosystem Assessment (2005). Ecosystems and human well-being -Biodiversity synthesis. World Resourses Institute, Washington DC. Erhållen Feb 7, 2010 från http://www. maweb.org/documents/document.354.aspx.pdf

Molander, P. (2008). Biologisk mångfald: En analys av begreppet och dess användning $i$ den svenska miljöpolitiken. Stockholm: Finansdepartementet, Regeringskansliet.

Nelson, J. (2006). Hur används läroboken av lärare och elever? NorDiNa 3(4),16-27.

Oscarsson, M., Jidesjö, A., Karlsson, K-G., \& Strömdahl, H. (2009). Science in society or science in school: Swedish secondary school science teachers' beliefs about science and science lessons in comparision with what their students want to learn. NorDiNa 5(1), 18-34.

Robson, C. (2002). Real world research: A resource for social scientists and practitioner-researchers. (2:a uppl.) Blackwell: Oxford.

Schreiner, C., \& Sjøberg, S. (2004). Sowing the seeds of ROSE. Background, rationale, questionnaire development and data collection for ROSE (The relevance of science education) - a comparative study of students' views of science and science education. Acta Didactica Dept. of Teacher education and school development, Oslo: University of Oslo.

Selander, S., \& Skjelbred, D. (2004). Pedagogiske tekster for kommunikasjon och laring. Oslo: Universitetsforlaget.

Sjøberg, S. (2010). Naturvetenskap som allmänbildning - En kritisk ämnesdidaktik. (3:e uppl.) Lund: Studentlitteratur.

Skolverket (2006). I enlighet med skolans värdegrund?: en granskning av hur etnisk tillhörighet, funktionshinder, kön, religion och sexuell läggning framställs $i$ ett urval av läroböcker. Stockholm: Skolverket.

Skolverket (2008). Grundskolan: kursplaner och betygskriterier: förordning (SKOLFS 200:135) om kursplaner för grundskolan: Skolverkets föreskrifter (2000:141) om betygskriterier för grundskolans ämnen. (2., rev. uppl.) Stockholm: Skolverket.

SÖ 1993:77. Konvention om biologisk mångfald. Erhållen Nov 22, 2007 från Konventionen om biologisk mångfald. http://www.biodiv.se/pdfer/1993_77.pdf

TEEB, The economics of ecosystems \& biodiversity (2008) European communities. Erhållen Feb 8, 2010 från http://www.teebweb.org/LinkClick.aspx?fileticket=5y_qRGJPOao\%3d\& tabid $=1018 \&$ language $=$ en-US

Tracana, R., Ferreira, M., Ferreira, C. \& Carvalho, G. (2008). Biodiversity in school textbooks of 13 countries. European researchers in didactics of biology 7, Zeist, 2008 - "ERIDOB 2008: "European Researchers in Didactics of Biology".

Yasan, O., \& Seremet, M. (2007). A comparative analysis regarding pictures included in secondary school geography textbooks taught in Turkey. International Research in Geographical and Environmental Education, 16(2), 157-187. 